\title{
CONHECENDO OS EUS DE PESSOA COM BERARDINELLI
}

\author{
Monique Pereira da Silva \\ Mestranda em Literatura Portuguesa pela Universidade do Estado do Rio de Janeiro \\ mniqueps@gmail.com
}

\section{RESENHA}

BERARDINELLI, Cleonice. Fernando Pessoa: os vários eus. In: Fernando Pessoa: outra vez te revejo. Rio de Janeiro: Lacerda Editores, 2004, p. 93-103.

Cleonice Serôa Berardinelli nasceu em 28 de agosto de 1916, na cidade do Rio de Janeiro. Cursou Letras na USP, em 1938, e no ano de 1959, tornou-se professora de Literatura Portuguesa, na Faculdade Nacional de Filosofia, quando defendeu sua primeira tese, "Poesia e poética de Fernando Pessoa", dedicada a Fernando Pessoa em terras brasileiras (e a segunda no mundo). Também é especialista em estudos sobre Gil Vicente e Camões, com um vasto número de obras publicadas, dentre elas: Estudos camonianos (1973); Obra em prosa: Fernando Pessoa (1974); Estudos de Literatura Portuguesa (1985); Álvaro de Campos - A passagem das horas (1988); Poemas de Álvaro de Campos (1990) e Fernando Pessoa: outra vez te revejo... (2004). Em 2009, Cleonice foi eleita membro efetivo da Academia Brasileira de Letras, tomando posse em abril de 2010.

No capítulo "Fernando Pessoa: os vários eus", o texto é estruturado de uma forma que evidencia a proposta de sua autora, em fazer uma comparação entre os heterônimos de Fernando Pessoa com o uso de citações do próprio, que por sua vez, relatam como 
surgiu cada heterônimo, assim, como as suas biografias, a personalidade e as principais características físicas e psíquicas de cada um deles.

Na edição projetada de Fernando Pessoa, "O Autor humano destes livros não conhece em si personalidade nenhuma", fazendo a dissociação de personalidade, o autor destes livros nem o contesta, nem o apoia, ou se "concordasse com esta ou aquela teoria, sobre os resultados escritos dessa multiplicidade" (BERARDINELLI, 2004, p. 93). Pessoa produz uma literatura para se divertir, e frequentemente, identifica-se com Shakespeare, por sentir-se com um temperamento dramático elevado ao máximo, mas que vai escrever, em vez de dramas em atos e ação, dramas em almas, porque é "um poeta dramático".

Desde criança criara um mundo de seres, pela imaginação. Tinha grande capacidade de efabulação, o que perdurou até a idade adulta, dando origem aos heterônimos literários que conhecemos.

De forma instintiva e subconsciente, era um discípulo de Alberto Caeiro, "desculpe-me o absurdo da frase: aparecera em mim o meu mestre". Arrancando de seu falso paganismo, o Ricardo Reis latente, "descobri- the o nome e ajustei-o" (BERARDINELLI, 2004, p. 95, que oposto à Ricardo Reis, surge a Ode Triunfal de Álvaro de Campos. Caeiro é repleto de despersonalização dramática; Ricardo Reis tem a "minha disciplina mental, vestida de música que lhe é própria” (BERARDINELLI, 2004, p. 96), e, Álvaro de Campos, toda a emoção.

Segundo Berardinelli, Pessoa destaca em absoluto essa diversificação de estilo correspondente à heteronímia, que ele vai justificar como existente no lirismo do último grau, que ele pratica. O autor entende que da poesia lírica à dramática, há uma gradação contínua, que vai às mesmas origens da poesia dramática, como a que está presente em 
Ésquilo, por exemplo, será a mesma que encontraremos na boca de diversos de seus personagens. Diz que o primeiro grau da poesia lírica é o que o poeta "concentrado no seu sentimento, exprime esse sentimento" (2004, p. 96). Chegando ao passo final que, teremos um poeta que seja vários poetas, com desdobramentos de personalidades ou invenções de personalidades diferentes, como um poeta dramático, que vai escrever em poesia lírica, com estilo próprio, até aos típicos do poeta na sua pessoa viva, passando por uma voluntariedade e uma involuntariedade coexistentes, do próprio poeta que hesita ou o "médium" de figuras que ele próprio criou.

Nos poemas de Pessoa, não devemos buscar ideias ou sentimentos do próprio autor, fato que faz confirmarmos a independência entre os heterônimos, o que faz-nos ver que definem- se, louvam-se ou criticam-se mutuamente, à exceção de Caeiro, que não tem nenhum texto em prosa. Álvaro de Campos faz apreciações sobre Fernando Pessoa, dizendo que sua força jaz, mais na análise intelectual do sentimento e da emoção, que o levou a uma perfeição. No ensaio "Athena", a filosofia - isto é, a metafísica - não é uma ciência, mas uma arte, e parece que Fernando Pessoa confunde o que a arte é, com o que a ciência não é.

O autor julga com bom senso de humor, a poesia de Ricardo Reis: "se é que ele usa de inspiração" (BERARDINELLI, 2204, p. 98), a preocupação com as sílabas, os versos e a altura do poema. Reis tem o pensamento sóbrio, denso e de emoção real; também emite opiniões sobre Campos, irmão em Pessoa: "Campos é grande prosador" (BERARDINELLI, 2004, p. 99), o ritmo da sua prosa tem vulgares sinais de pontuação, numa linha disposta como o que se chama um verso.

O mais analisado pelos outros heterônimos é Alberto Caeiro, de quem todos se consideram discípulos. Pessoa ao criá-lo, sentiu que nascera em si o seu mestre Ricardo 
Reis e declara que concedeu que pudesse considerar-se discípulo do poeta. Álvaro de Campos escreve "Notas para a recordação do meu mestre Caeiro", com admiração e ternura.

Ricardo Reis estuda e valoriza a obra de Caeiro, observando os elementos inesperados e complexos, a naturalidade e a espontaneidade de seus poemas, rigorosamente unificados para um pensamento filosófico que coordena e concatena, prevê objeções, antevê críticas e explica defeitos para a integração na obra. "A obra de Caeiro representa a construção integral do paganismo, na sua essência absoluta" (2004, p. 100), que nem os gregos nem os romanos puderam fazer. Menciona também os defeitos de Caeiro, no entanto, mais evidente é a forma poética dotada, que é, para ele, inadmissível; o mais grave para ele e o menos para os outros, é o "banho morno" da emotividade cristã, com a sua simbologia cristista. Em "O guardador de rebanhos" e no "O pastor amoroso", Caeiro apresenta uma filosofia surpresa, em que seus princípios sofrem uma derrota que representa a vitória ignóbil de uma revolução de escravos.

Fernando Pessoa quando fala de seus "filhos" demonstra que Álvaro de Campos está no ponto oposto a Ricardo Reis. "A sensação é tudo, afirma Caeiro, e o pensamento é doença" (BERARDINELLI, 2004, p. 101), sem acrescentar quaisquer elementos do pensamento pessoal, convenção, sentimento ou qualquer outro lugar da alma. Para Campos, a sensação é tudo, mas a sensação das coisas como são sentidas, todas as espécies de sensações das coisas e até da mesma coisa. Ele quer "sentir tudo de todas as maneiras" (BERARDINELLI, 2004, p. 102), sentir a cidade como sente o campo, o mal como o que é bom, nunca fazendo perguntas, só sente como um "filho indisciplinado da sensação". Caeiro tem uma disciplina: as coisas são sentidas, não somente como são, mas 
também de modo a coincidir com certo ideal de medida e de regra clássica. Para Álvaro de Campos, as coisas devem ser simplesmente sentidas.

A ética de Caeiro é a simplicidade; em Ricardo Reis é pagã, meio epicurista e estoica, bem definida e de elevação na sua poesia, o que Caeiro não pode obter. Álvaro de Campos não tem sombra de ética, é amoral, imoral, prefere as sensações mais fortes (egoísmo, crueldade e luxúria), assemelha-se a Witman, entretanto distanciado da multidão, e, quando perto, é para agradar a si mesmo. Ricardo Reis não fere ninguém, “é moral porque basta a si próprio" (BERARDINELLI, 2004, p. 103). Caeiro cria um mundo com várias espécies de subjetivismos, traz ao mesmo tempo, o objetivismo absoluto, mais que os objetivismos pagãos, trazendo uma natureza absoluta, num mundo supercivilizado, com humanitarismos: problemas operários, sociedades éticas, movimentos sociais, desprezo pelo destino e vida do homem, de forma excessiva, mas "corretivo magnífico".

Recebido em 29 de agosto de 2018.

Aceite em 20 de novembro de 2018. 